\title{
Community-acquired pneumonia associated with cytomegalovirus persistence: prevalence and peculiarities of clinical course
}

\section{K. D. Chichirelo-Konstantynovych}

National Pirogov Memorial Medical University, Vinnytsia, Ukraine

Key words: cytomegalovirus, pneumonia, PORT, antibodies.

Zaporozhye medical journal 2018; 20 (3), 366-370

DOl:

10.14739/2310-1210

2018.3.132125

E-mail:

konstantinovichk@

yahoo.com
The article discusses the problem of cytomegaloviral persistence asymptomatic course among young patients with communityacquired pneumonia and in healthy population group based on specific immunoglobulins $M$ and $G$ appearance in blood and antibody avidity value (the duration of persistent). The connection between viral persistence and prognosis of community-acquired pneumonia course (by pneumonia severity index in PORT) is also recognized.

Aim of the scientific work is to study the prevalence of cytomegaloviral persistence among young patients with community-acquired pneumonia for optimization the plan of clinical examination and prognosis for this patient category.

Materials and methods. One hundred and five patients with community-acquired pneumonia and 61 healthy individuals (aged from 18 to 44 years) were examined for cytomegaloviral biomarkers (CMV IgG, CMV IgG avidity) and by PORT-scale. Positive result for viral persistence was compared with gender, age subtypes and pneumonia severity index in both groups.

Results. Cytomegaloviral persistence prevalence rate among patients with community-acquired pneumonia was $48.2 \%$ versus $20.5 \%$ among healthy individuals $(P=0.003)$. The patients with community-acquired pneumonia had higher CMV IgG avidity value $(P=0.007)$, it was more common for female patients $\left(P=0.043 ; X^{2}=8.164\right)$. The cytomegaloviral persistence prevalence increased with age $(P=0.045)$ and correlated with pneumonia severity index according to PORT-scale $(P<0.0001)$.

Conclusions. The patients with community-acquired pneumonia differ in significantly higher cytomegaloviral prevalence rate $(P=0.003)$ from the healthy respondents. This rate increases with age, negatively impacts the pneumonia prognosis (by PORT-score). The duration of cytomegaloviral persistence (based on the CMV IgG avidity value recognition) does not depend on age in both comparison groups $(P>0.05)$.
Киючові слова: цитомегаловірус, пневмонія, PORT, антитіла.

Запорізький медичний T. 20, № 3(108), C. $366-370$ журнах. - 2018. -

\section{Негоспітальна пневмонія при цитомегаловірусній персистенції: поширеність та особливості перебігу}

\section{К. А. Чічірельо-Константинович}

Порушена проблема безсимптомної цитомегаловірусної персистенції серед контингенту хворих на негоспітальну пневмонію, а також на популяційному рівні на підставі виявлення специфічних антитіл класу імуноглобулінів М і G, тривалості персистенції (відповідно до авідності анамнестичних антитіл). Розкрито зв'язок між наявною вірусною персистенцією та прогнозом важкості перебігу негоспітальної пневмонії згідно зі шкалою ризику летальних наслідків PORT.

Мета роботи - дослідити поширеність цитомегаловірусної персистенції в молодого контингенту хворих на негоспітальну пневмонію для оптимізації плану обстеження та прогнозування таких пацієнтів.

Матеріали та методи. У пацієнтів молодого віку (18-44 роки) зі встановленим діагнозом негоспітальної пневмонії та контрольній групі практично здорових осіб вивчали поширеність цитомегаловірусної персистенції завдяки визначенню маркерів CMV IgG, CMV Ig (авідність), встановлювали зв'язок виявленої персистенції з особливостями за статтю та віком у групі порівняння та ризиком летальних наслідків за шкалою PORT в основній групі.

Результати. Показник поширеності цитомегаловірусної персистенції був вірогідно вищим у хворих на негоспітальну пневмонію та дорівнював 48,2 \%, у контрольній групі - 20,5 \% ( $p=0,003)$. Хворі основної групи мали вищі значення CMV $\lg$ авідності $(p=0,007)$, що більше виражена в жінок, які хворі на негоспітальну пневмонію, ніж у чоловіків $(p=0,043$; $\left.X^{2}=8,164\right)$. Показник цитомегаловірусної поширеності зростає з віком $(p=0,045)$ та корелює відповідно до класу ризику летальних наслідків за шкалою PORT $(p<0,0001)$.

Висновки. Пацієнти з негоспітальною пневмонією статистично значущо відрізняються від практично здорових респондентів популяції вищим показником поширеності цитомегаловірусної інфекції, що зростає відповідно до віку, негативно впливає на прогноз для таких хворих у вигляді асоціації з класом ризику летальних наслідків (за шкалою PORT). Tривалість цитомегаловірусної персистенції (відповідно до авідності антитіл) не залежить від віку в обох групах ( $p>0,05)$.

Киючевые слова: цитомегаловирус, пневмония, PORT, антитела.

\section{Негоспитальная пневмония при цитомегаловирусной персистенции: распространенность и особенности течения}

\section{К. А. Чичирельо-Константинович}

Поднята проблема бессимптомной цитомегаловирусной персистенции у контингента больных негоспитальной пневмонией и на популяционном уровне на основании определения специфических антител класса иммуноглобулинов $\mathrm{M}$ и $\mathrm{G}$, а также длительности персистенции (по авидности анамнестических антител). Раскрыта связь между наличием вирусной персистенции и прогнозом тяжести течения негоспитальной пневмонии в соответствии со шкалой риска летальных событий PORT. 
Цель работы - исследовать распространенность цитомегаловирусной персистенции у молодого контингента пациентов с негоспитальной пневмонией для последующей оптимизации схемы обследования и прогноза таких больных.

Материалы и методы. У пациентов молодого возраста (18-44 лет) с установленным диагнозом негоспитальной пневмонии и практически здоровых респондентов изучали показатель распространенности цитомегаловирусной персистенции путем установления маркеров CMV IgG, CMV lgG (авидность) в крови, исследовали связь персистенции с половыми и возрастными особенностями, а также риском летальных происшествий по шкале PORT в основной группе.

Результаты. Показатель распространенности цитомегаловирусной персистенции оказался статистически более высоким в группе больных негоспитальной пневмонией и составил $48,2 \%$, в группе здоровых $-20,5 \%(p=0,003)$. Пациенты основной группы характеризовались более высокими значениями CMV IgG авидности ( $p=0,007)$, что наиболее выражено у женщин с негоспитальной пневмонией, чем у мужчин $\left(p=0,043 ; x^{2}=8,164\right)$. Показатель цитомегаловирусной распространенности растет соответственно возрасту респондентов $(p=0,045)$ и коррелирует с классом риска летальных происшествий по шкале PORT $(p<0,0001)$.

Выводы. Пациенты с негоспитальной пневмонией отличаются от здоровых респондентов популяции более высоким показателем распространенности цитомегаловирусной персистенции, который увеличивается с возрастом, негативно влияет на прогноз для данной когорты пациентов в виде ассоциации с классом риска летальных последствий (по шкале PORT). Продолжительность цитомегаловирусной персистенции (по уровню авидности антител) не зависит от возраста в обеих группах $(p>0,05)$.

\section{Background}

The role of cytomegaloviral infection (CMVI) in immunosuppressive conditions complications remains great clinical problem in modern infectology, gynecology, pediatrics and immunology. However, every branch of medicine develops own unique guidelines to solve severe pathological effects of CMVI. After a primary infection, human CMVI remains latent in certain human cells. Different stimuli, including immune deficiency and severe infection, can trigger the reactivation of latent CMVI. In the last decade, the role of the reactivation in immunocompetent patients with serious illness has been intensively studied; however, the knowledge of the potential role of moderately severe infections on CMVI dynamics is limited [11]. For a long time CMVI has been recognized as one of the most important pathogens in immunocompromised patients, such as solid organ transplant recipients [1,13], patients with haematological malignancies [2], and HIV patients [6]. In the last decade the role of serious infections in activation of latent CMV infection in immunocompetent patients has also been scrutinized [10].

At the same time, scientific progress in the diagnosis of community-acquired pneumonia (CAP) and the development of highly effective antibacterial drugs for its treatment do not provide a full positive effect, which can be explained by the conditions of CAP occurrence transformation, changes in the virulence of pathogens and the immune reactivity of the patient's body $[9,12]$. The $35-60 \%$ of etiologically determined CAP is S. Pneumoniae. Viral etiology of CAP is extremely controversial. $10-30 \%$ of patients do not expectorate sputum, 15-30\% take antibiotics until a specific laboratory examination. In 30-65\% the data of microbiological / virological examination is questionable [7].

These facts suggest the probable possibility of avoiding the protective immune attack by some kind of latent persistent pathogen, which effects immunity, without specific clinical features, that results in superinfection and makes hidden conditions for bacterial comorbidities like CAP. The CMVI prevalence among young CAP patients has not been studied yet, though its knowledge can optimize specific etiological and immunological diagnostics and correct treatment.

\section{Aim}

Study of CMVI persistence among young CAP patients has the aim to correct the examination plan for making early CAP course prognosis.

\section{Materials and methods}

We examined 105 CAP patients (51 men (48.6\%), 54 women $(51.4 \%))$, average age of $(34.1 \pm 0.8)$ years old and 61 healthy individuals ( 26 men (42.6\%), 35 women $(57.4 \%))$, average age of $(31.4 \pm 0.9)$ years old. CAP was diagnosed clinically according Order № 128 of the Ministry of Health of Ukraine (2007) and the Clinical Instruction (2013) [5]. The Pneumonia Patient Outcomes Research Team (PORT) scale was used to assess the mortality risk factors according to existing requirements and for more objective stratification of patients. The pneumonia severity index (PSI) or PORT Score is a clinical prediction rule that medical practitioners can use to calculate the probability of morbidity and mortality among patients with community-acquired pneumonia. The PSI/PORT score is often used to predict the need for hospitalization in people with pneumonia. This is consistent with the conclusions stated in the original report that published the PSI/PORT score. We describe the prognostic approach which accurately identifies the patients with community-acquired pneumonia who are at low risk for death and other adverse outcomes. This prediction rule may help physicians make more rational decisions about hospitalization for patients with pneumonia. A Risk Class I or Risk Class II pneumonia patient can be sent home with oral antibiotics treatment. A Risk Class III patient after evaluation of other factors including home environment and follow-up care can be either sent home with oral antibiotics treatment or admitted for a short hospital stay with antibiotics and monitoring. Pneumonia Risk Class IV-V patients should be hospitalized for treatment [3].

CMVI persistence was identified by immune sorbent assay (specific CMV IgG, CMV IgG avidity) [4,8,14]. CMVI persistence was confirmed by positive for CMV IgG result. The CMV IgG avidity, as an indicator of CMVI persistence limitation, was analyzed by the following characteristics: 1-39 \% - low avidity, primary CMVI; 40-60 \% - interme- 
diate avidity, CMVI reconvalescent; >60 \% - high avidity, anamnestic CMV-antibodies.

Statistic processing of results was performed by SPSS 12.0 for Windows (Grand Pack, Serial Number 9593869). Previously, the verification of variables values on the normality of distribution by the Kolmogorov-Smirnov method was carried out. For the normality of variables determination for Puasson distribution with insignificant probability of error $(P>0.05)$, parametric tests were used for further statistical analysis (Student's t-test for two dependent or independent variables (sampling), a simple analysis of variance (ANOVA) was used for more than 2 independent variables and a simple dispersion analysis with repeated measurements was used for more than 2 dependent variables (samples). Non-parametric tests (U-Mann-Whitney test for 2 independent variables (samples), Wilcoxon test for two dependent variables (samples) comparison, Kruskal-Wallis $\mathrm{H}$ test for more than 2 independent variables (samples) comparison and the Friedman test to compare more than two dependent variables (selections) that allow one to examine the effect of one or more independent variables on dependent variable were used in case of non-normal distribution of variables.

Descriptive methods were compiled by constructing cross-tables, statistics for $\chi^{2}$ for the nominal scale, comparing two independent samples (Student's T-criterion), oneway ANOVA one-dimensional analysis (Fisher's F-criterion), Scheffe's and Duncan's posteriori test for comparison of average values. Spearman rank correlation was used for associative connections revealing between score characteristics and clinical features of CAP, which belonged to the interval scale, in connection with the non-compliance of the mentioned indices with normal distribution. The investigated values are represented as "average \pm standard error of average value" ( $\mathrm{M} \pm \mathrm{m})$ or "average \pm standard deviation" $(M \pm \sigma)$. The results of comparisons were considered to be significant when the probability of error $(p)$ was not more than 0.05 .

\section{Results and discussion}

The CMVI prevalence (according to CMV IgG appearance) among CAP patients was revealed significantly higher than in the control group $(P=0,003)$. The results are shown in Table 1.

The average titer of CMV IgG among CAP patients was $(6.86 \pm 0.70)$ and ranged from 0.0 to 39.1 , while in the group of healthy individuals the average titer of CMV $\mathrm{lgG}$ was $(5.26 \pm 0,70)$ and ranged from 0.0 to 18.3 (the difference was insignificant, $t=1.581, P=0.701)$. The average titer of CMV IgG was $(6.29 \pm 0.70)$ and ranged from 0 to 39 among all respondents ( 166 observations). Thus, there was a tendency toward an increasing in the absolute value of the average titer of CMV IgG in the group of CAP patients in comparison with the control group.

Classification of all respondents according CMV IgG avidity showed in both groups of comparison that CMV-positive respondents in the majority of cases had high CMV IgG avidity, indicating rather a long CMV persistence in these respondents. It is also noteworthy that the percentage of different values avidity among patients with CAP was higher than among practically healthy persons $(P=0.007): 48.6 \%$ vs $45.9 \%$ (high avidity), $21.9 \%$ vs $8.2 \%$ (intermediate avidity) and $6.7 \%$ vs $1.6 \%$ (low avidity) (Table 2).

Gender characteristics of the classified respondents in both comparison groups revealed that among CAP patients male significantly differed from women $(P=0.043$; $\left.X^{2}=8.164\right)$ : intermediate CMV IgG avidity value was $15.2 \%$ among males (16 persons) versus $6.7 \%$ (7 persons) among females, high CMV IgG avidity was detected in 18 men $(17.1 \%)$ and 33 women $(31.4 \%)$. A similar analysis in the control group did not reveal significant difference according to gender $\left(X^{2}=2.244 ; P=0.523\right)$.

Analysis of CMVI prevalence (by CMV IgG appearance) according to age found significantly increased number of CMV-positive individuals among elderly CAP patients $(P=0.045): 1.0 \%$ - in category of 20-29 years old, $3.8 \%$ in category of 30-39 years old, $16.2 \%$ - in category of 40-44 years old. Analysis of CMVI prevalence (by CMV IgG avidity) according to age did not find significant differences neither among CAP patients $\left(X^{2}=11.402 ; P=0.249\right)$ nor among healthy persons $\left(X^{2}=4.793 ; P=0.852\right)$.

We also tried to reveal the dependence of CAP prognosis on CMV IgG avidity.

Results are given in Table 3.

The proportion calculation among patients with CAP according to its severity and the value of CMV IgG avidity was performed in CMV-positive respondents of the main group (80 persons). CMV-positive CAP patients with high CMV IgG avidity differed in CAP severity $(P<0.0001)$ : PORT I was defined in $5(6.3 \%)$ persons, PORT II - in $22(27.5 \%)$ patients, PORT III-in $17(21.3 \%)$ persons. A similar feature was found among CMV-positive patients with low CMV IgG avidity: patients with PORT I were not found, PORT II and III were diagnosed in 3 patients $(3.7 \%)$ in each group, PORT IV was detected in $7 \%$ (1 patient). Thus, we have found a direct relationship between CAP progressive severity and CMVI duration.

Our clinical research shows significantly high level of undiagnosed persistent CMVI incidence among young individuals. Official data of CMVI prevalence speaks about $30 \%$ of world population under 30 years of age with positive CMV IgG [11]. We enrolled the individuals 18-44 years old (young category) in the study. The different CMV-indexes in our work (48.2\% among CAP patients and $20.5 \%$ among healthy individuals) may be associated with immune response peculiarities, therefore only respondents without comorbidities were included in the study. That is why CMVI persistence can lead to some immune system dysfunction, which influences the severity of pneumonia course.

The fact of significantly higher CMV IgG content in CAP patients than among healthy ones may explain the susceptibility of CMV-positive individuals to different bacterial associations (including CAP).

The persistence avidity index among all respondents is responsible for CMVI duration: the high avidity value is a result of long-term viral persistence $[2,8,10]$. The higher CMV IgG avidity among CAP patients confirms already known data and shows that CMV persistence increases the risk of additional bacterial comorbidities.

The gender difference according to CMVI presence needs additional study. The longer CMVI duration among females versus males can be the result of transmission features and may deal with hormonal differences, which have not been investigated yet. 
Table 1. The cytomegaloviral prevalence among patients with community-acquired pneumonia and healthy individuals

\begin{tabular}{|c|c|c|c|c|c|c|c|}
\hline \multirow[t]{2}{*}{ CMVI persistence } & \multicolumn{2}{|c|}{ CAP patients $(n=105)$} & \multicolumn{2}{|c|}{ Healthy individuals $(n=61)$} & \multirow[t]{2}{*}{$x^{2}$} & \multirow{2}{*}{$\begin{array}{l}r \\
\text { (Spirmen's) }\end{array}$} & \multirow[t]{2}{*}{$p$} \\
\hline & $\mathrm{n}$ & $\%$ & $\mathrm{n}$ & $\%$ & & & \\
\hline \multicolumn{8}{|l|}{$\operatorname{lgG}$ CMV } \\
\hline - positive & 80 & 48.2 & 34 & 20.5 & \multirow[t]{3}{*}{8.685} & \multirow[t]{3}{*}{-0.228} & \multirow[t]{3}{*}{0.003} \\
\hline - doubtful & 1 & 0.6 & - & - & & & \\
\hline - negative & 24 & 14.5 & 27 & 16.3 & & & \\
\hline
\end{tabular}

Table 2. Classification of patients with community-acquired pneumonia and healthy individuals according to CMV IgG avidity

\begin{tabular}{|c|c|c|c|c|c|c|c|}
\hline \multirow[t]{2}{*}{ Value of CMV IgG avidity } & \multicolumn{2}{|c|}{ CAP patients $(n=105)$} & \multicolumn{2}{|c|}{ Healthy individuals $(n=61)$} & \multirow[t]{2}{*}{$x^{2}$} & \multirow{2}{*}{$\begin{array}{l}r \\
\text { (Spirmen's) }\end{array}$} & \multirow[t]{2}{*}{$P$} \\
\hline & n & $\%$ & $n$ & $\%$ & & & \\
\hline Low - primary infection (1-39 \%) & 7 & 6.7 & 1 & 1.6 & \multirow[t]{3}{*}{12.134} & \multirow[t]{3}{*}{-0.116} & \multirow[t]{3}{*}{0.00} \\
\hline Intermediate -reconvalescence (40-60\%) & 23 & 21.9 & 5 & 8.2 & & & \\
\hline High - anamnestic antibodies (>60 \%) & 51 & 48.6 & 28 & 45.9 & & & \\
\hline
\end{tabular}

Table 3. Dependence of community-acquired pneumonia prognosis (according to PORT-scale) on CMV IgG avidity

\begin{tabular}{|c|c|c|c|c|c|c|c|c|c|c|c|c|c|}
\hline \multirow[t]{3}{*}{ Value of CMV IgG avidity } & \multicolumn{8}{|c|}{ PSI } & \multirow{2}{*}{\multicolumn{2}{|c|}{ Total $(n=80)$}} & \multirow[t]{3}{*}{$x^{2}$} & \multirow{3}{*}{$\begin{array}{l}\mathbf{r} \\
\text { (Spirmen's) }\end{array}$} & \multirow[t]{3}{*}{$\mathbf{P}$} \\
\hline & \multicolumn{2}{|c|}{ PORT I $(n=5)$} & \multicolumn{2}{|c|}{ PORT II $(n=38)$} & \multicolumn{2}{|c|}{ PORT III ( $n=28)$} & \multicolumn{2}{|c|}{ PORT IV $(n=9)$} & & & & & \\
\hline & $n$ & $\%$ & $n$ & $\%$ & $n$ & $\%$ & $n$ & $\%$ & $n$ & $\%$ & & & \\
\hline Low (1-39 \%) & - & - & 3 & 3.7 & 3 & 3.7 & 1 & 7 & 15 & 8.8 & 31.446 & 0.305 & $<0.0001$ \\
\hline Intermediate (40-60\%) & - & - & 13 & 16.2 & 8 & 10.0 & 2 & 2.5 & 23 & 28.7 & & & \\
\hline High $(>60 \%)$ & 5 & 6.3 & 22 & 27.5 & 17 & 21.3 & 6 & 7.5 & 50 & 62.5 & & & \\
\hline
\end{tabular}

There is an increasing tendency of CMVI persistence with age [8], which is confirmed by our results. So the risk of latent CMVI appearance increases with age and all supposed immunological dysfunctions depend on contributing individual and environmental factors for its clinical manifestation (CAP is among them).

The clinical relevance of our study was based on comparison of CAP severity and CMVI duration. The obtained results give a clear picture of direct dependence: the growth of PSI is accompanied by CMV IgG avidity increase. Such dependence goes to prove that long-term CMVI persistence complicates the course of CAP through certain pathogenetic mechanisms.

\section{Conclusions}

1. CAP patients differ from healthy individuals by higher incidence of CMVI persistence, which leads to CMV IgG level elevation in blood samples. The value of CMVI persistence among young patients with CAP ranges $48.2 \%$ versus $20.5 \%$ of control healthy ones $(P=0.003)$.

2. CAP respondents have a tendency toward an increase in the average titer of CMV IgG absolute value. According to all values of CMV IgG avidity CAP patients are characterized by longer viral persistence period than control group respondents $(P=0.007)$, which is particularly in evidence $\left(P=0.043 ; X^{2}=8.164\right)$ among CAP females.

3. CMVI prevalence among CAP patients has an increasingly positive association with the age $(P=0.045)$ and depends on PSI $(P<0.0001)$.

Prospects for further research. The obtained results will have a continuation on the look-out for pathological mechanisms of CMVI influence on immunological, genetic, hormonal links among young individuals in order to prevent bacterial comorbidities (CAP as well). New discoveries in this area will allow optimizing the clinical, diagnostic and therapeutic approach, predicting the course of CAP and preventive measures developing.

Conflicts of Interest: author has no conflict of interest to declare. Конфлікт інтересів: віАсутній.

Information about author:

Chichirelo-Konstantynovych K. D., MD, Postgraduate

student, Department of Infectious Diseases with the course of Epidemiology, National Pirogov Memorial Medical University, Vinnytsia, Ukraine.

\section{Відомості про автора:}

Чічірельо-Константинович К. А., аспірант каф. інфекційних хвороб із курсом епідеміології, Вінницький національний медичний університет імені М. І. Пирогова, Україна.

\section{Сведения $о б$ авторе:}

Чичирельо-Константинович К. А., аспирант

каф. инфекционных заболеваний с курсом эпиАемиологии, Винницкий национальный медицинский университет имени Н. И. Пирогова, Украина.

НаАійшла Ао реАакції / Received: 09.11.2017

Після Аоопрацювання / Revised: 15.11.2017

Прийнято АО Аруку / Accepted: 17.11.2017

\section{References}

[1] Bao, L., Cowan, M., Dunham, K., Horn, B., McGuirk, J., Gilman, A., \& Lucas, K. (2012). Adoptive Immunotherapy With CMV-specific Cytotoxic T Lymphocytes for Stem Cell Transplant Patients With Refractory CMV Infections. Journal Of Immunotherapy, 35(3), 293-298. doi: 10.1097/ CJl.0b013e31824300a2. 
[2] Cook, C., Trgovcich, J., Zimmerman, P., Zhang, Y., \& Sedmak, D. (2006). Lipopolysaccharide, Tumor Necrosis Factor Alpha, or Interleukin-1 Triggers Reactivation of Latent Cytomegalovirus in Immunocompetent Mice. Journal Of Virology, 80(18), 9151-9158. doi: 10.1128/JVI.00216-06.

[3] Chalmers, J., Singanayagam, A., Akram, A., Mandal, P., Short, P. Choudhury, G., et al. (2010). Severity assessment tools for predicting mortality in hospitalised patients with community-acquired pneumonia. Systematic review and meta-analysis. Thorax, 65(10), 878-883. doi: $10.1136 /$ thx.2009.133280.

[4] Eguchi, H., Horita, N., Ushio, R., Kato, I., Nakajima, Y., Ota, E., \& Kaneko, T. (2017). Diagnostic test accuracy of antigenaemia assay for PCR-proven cytomegalovirus infection-systematic review and meta-analysis. Clinical Microbiology And Infection., 23(12), 907-915. doi: 10.1016/j.cmi.2017.05.009.

[5] Feshchenko, Yu. I., Holubovska, O. A., \& Honcharov, K. A. (2014). Nehospitalna ta hospitalna (nozokomialna) pnevmoniia u doroslykh osib: etiolohiia, patohenez, klasyfikatsiia, diahnostyka, antybakterialna terapiia [Community-acquired and nosocomial pneumonia in adults: etiology, pathogenesis, classification, diagnostics, antibiotic therapy]. Kyiv. [in Ukrainian].

[6] Goussard, P., Kling, S., Gie, R., Nel, E., Heyns, L., Rossouw, G., \& Janson, J. (2010). CMV pneumonia in HIV-infected ventilated infants. Pediatric Pulmonology, 45(7), 650-655. doi: 10.1002/ppul.21228.

[7] Lim, W. S., Baudouin, S. V., George, R. C., Hill, A. T., Jamieson, C., Le Jeune, I., et al. (2009). British Thoracic Society guidelines for the management of community acquired pneumonia in adults: update 2009. Thorax, 35(3), 293-298. doi: 10.1136/thx.2009.121434.

[8] Palasanthiran, P., Starr, M., \& Jones, C. (2014). Management of Perinatal Infections Australian Society for Infectious Diseases, 6-10.

[9] Quan, T., Fawcett, N., Wrightson, J., Finney, J., Wyllie, D., Jeffery, K., et al. (2016). Increasing burden of community-acquired pneumonia leading to hospitalisation, 1998-2014. Thorax, 71(6), 535-542. doi: 10.1136/ thoraxjnl-2015-207688.

[10] Reeves, M., \& Sinclair, J. (2008). Aspects of human cytomegalovirus latency and reactivation. Curr. Top. Microbiol. Immunol., 325, 297-313. https://doi.org/10.1007/978-3-540-77349-8_17.

[11] Saletinger, R., Poljak, P., \& Strle, F. (2015). Presence of human cytomegalovirus DNA in blood of patients with community-acquired pneumonia. Clinical Microbiology and Infection, 21(1), 97-102. doi: 10.1016/j.cmi.2014.09.001.

[12] Tang, L., Li, Q., Bai, J., Zhang, H., Lu, Y., \& Ma, S. (2014). Severe Pneumonia Mortality in Elderly Patients Is Associated With Downregulation of Toll-like Receptors 2 and 4 on Monocytes. The American Journal Of The Medical Sciences, 347(1), 34-41. doi: 10.1097/ MAJ.0b013e3182798583.

[13] Toussaint, N., Tan, M., Nicholls, K., Walker, R., \& Cohney, S. (2011). Low-dose valaciclovir and cytomegalovirus immunoglobulin to prevent cytomegalovirus disease in high-risk renal transplant recipients. Nephrology, 16(1), 113-117. doi: 10.1111/j.1440-1797.2010.01379.x.

[14] Welten, S. P. M., Redeker, A., Toes, R. E. M., \& Arens, R. (2016) Viral Persistence Induces Antibody Inflation without Altering Antibody Avidity. Journal of Virology, 90(9), 4402-4411. doi: 10.1128/JVI.03177-15. 